\title{
THE INFLUENCE OF PRINCIPAL'S ROLE AND WORK MOTIVATION TO TEACHERS JOB SATISFACTION
}

\author{
Ipong Dekawati ${ }^{*}$, Wresni Pujiyati2 ${ }^{2}$, Siwi Sitoresmi ${ }^{3}$ \\ 1,2,3 Universitas Wiralodra, Indramayu, Indonesia \\ *ipongdekawati@unwir.ac.id
}

\begin{tabular}{l}
\hline \hline Article Info \\
\hline Article history \\
Received: December 11, 2020 \\
Revised: December 21, 2020 \\
Accepted: December 28, 2020 \\
\hline
\end{tabular}

\section{Keywords:}

Job Satisfaction;

Principal's Role;

Work Motivation.

\begin{abstract}
Job satisfaction as a support for the implementation of teacher's functional tasks is still lacking. Based on preliminary observations, it thought that this caused by the lack of the principal's role and work motivation. Therefore, this study aims to uncover the influence of the principal's role and work motivation on public middle school teachers' job satisfaction. The hypotheses of this study are: (1) The principal's role influence the job satisfaction of public middle school teachers, (2) The work motivation influence the job satisfaction of public middle school teachers, (3) Principal's role and work motivation together influence the job satisfaction of public middle school teachers. This study uses a survey method with a quantitative approach, correlational and regression techniques-data collection techniques through a Likert scale questionnaire of 59 respondents who are public middle school teachers. The results of data analysis show that (1) the principal's role influences the job satisfaction of public middle school teachers, (2) Work motivation influences the job satisfaction of public middle school teachers, (3) Principal's role and work motivation together influences the job satisfaction of public middle school teachers. Based on these findings, the authors suggest that some improvement efforts can be made, especially in increasing teacher job satisfaction, including involving teachers in further education and providing encouragement to start creatively and achieving, mobilizing the learning outcome evaluation team, and following the development of science, technology, and the arts, exemplify good models of learning and counselling.
\end{abstract}

\section{INTRODUCTION}

Education is the spearhead in improving society's welfare because quality human resources (HR) are a measure of the progress of a nation and state. Referring to Law Number 20 of 2003 concerning the National Education System, improving the quality of education requires teachers' role as educators. The role generally summarized in three main points: a provider of a conducive educational atmosphere, professional staff with full commitment to improving the quality of education, and role models to maintain the good name of institutions and professions. As a service-based profession, teachers often seen as a profession with relatively high challenges than other professions (Travers \& Cooper, 1996). As long as they fulfil their workload, teachers must interact with students, parents, fellow teachers, and school 
principals, each of whom has different problems and demands. On the other hand, workrelated pressures such as meeting deadlines for curriculum needs, changing curriculum, adapting processes to unhealthy working conditions, and dealing with problem students are also among the teachers' challenges. Stant exposure of teachers to this situation, if not appropriately handled mostly in terms of reward, can lead to low teacher job satisfaction (Suputra et al., 2019).

Based on the results of pre-observations and informal interviews by the author with several junior high school teachers in Brebes, it known that there are still teachers who feel that even though they work with sufficient wages, there are several things that limit the space for social activities carried out together, especially in research. The assistance provided is limited, and promotion opportunities in structural positions are also minimal. In general, the teachers expressed pride in their status as teachers at the school where they taught. However, several things were deemed inappropriate, among others: 1) there was a gap between payment and the increasing workload, 2) lack of opportunities for promotion, especially for young teachers, even though the level of education and ability to sit in structural positions was sufficient, and 3) supervision from the principal is still normative, not specifically directing the development of professionalism, especially in terms of research. This condition certainly needs to get more attention from the principal because low teacher job satisfaction can lead to low performance (Sari, 2018) and the commitment of teachers to be involved in making much effort to help their schools become better (Saepudin \& Djati, 2019).

When referring to the pre-observations results above, it indicated that elements of the principal's role have the potential to affect the level of teacher job satisfaction while carrying out their responsibilities. To optimize teacher job satisfaction, ideally, the principal can play his role as a leader by showing attention and providing assistance to teachers who have difficulty completing their work. It is understandable considering the school as an organization; a school principal leads its management. However, generally, the principal in Indonesia cannot be said to be a professional manager. It is in line with the World Bank report that one of the causes of the decreasing quality of education in Indonesian schools is the lack of professionalism in school principals' role (Mulyasa, 2004).

The writer found that the role of school principals in SMP had not optimally implemented. For example, there are still principals who do not yet have the ability as an educator. In this case, the principal seems to lack facilitation and encouragement for teachers to improve their competence so that the learning process does not run effectively and efficiently. Furthermore, there are still principals who have not optimized their roles as managers.

It is evident from the lack of facilities for education and training activities for teachers such as the school-level MGMP/ MGP. Also, there are still principals who do not fully have the ability as innovators. Some of them were unable to analyze the strengths, weaknesses, opportunities and challenges of their respective schools, tending to wait for what education 
officials said. On the other hand, the principal's is lack of ability as a motivator. It can saw disciplined in carrying out their duties so that they are unable to increase teacher work motivation.

From the phenomenon, it can saw that to achieve quality performance as expected; the principal must have adequate knowledge and skills to act as a teacher leader. Achieving educational programs in schools will be very difficult to achieve without harmonizing views between the principal and the teacher regarding how schools' education process should implement (Abdullah, 2017).

This harmony can form when the principal can effectively recognize the teachers' character and master the techniques of giving orders and delegating tasks, is fair in giving awards and warnings, and can provide motivation to be actively involved in decision making related to various school programs. Collaboration between school principals and teachers related to decision making can form perceptions in teachers that they have abilities recognized by their leaders to increase teacher satisfaction with the work they have done (You et al., 2017). Thus, the more optimal the role of the principal, the potential to increase teacher job satisfaction.

Teacher job satisfaction is synonymous with self-evaluative assessments related to the work he has done. In this case, teacher job satisfaction is also often associated with affective reactions to the role of teaching carried out on students' academic progress (Skaalvik \& Skaalvik, 2017).

The findings of Skaalvik and Skaalvik (2017) and Türkoğlu et al. (2017) show that if teachers have the perception that the teaching they have done results in high academic mastery for their students, then this perception will lead to high teacher satisfaction with their work performance.

On the other hand, the meaning of work arises when it based on the high aspects of interest, desire and curiosity for quality work results (Williams \& Burden, 1997). These aspects are work motivation builders that function as driving or weaker for a person's desire to change intentions into action and start doing something new or starting over something that has done (Singh \& Sharma, 2016). It indicates that another factor that has the potential to influence teacher job satisfaction is work motivation.

Motivation is the willingness of individuals to make high efforts to achieve goals based on two building factors, namely external and internal sides (Rivai, 2004). Motivation can also be a potential strength that can be developed by oneself or by other strengths, the number of which is influenced by the strength of self-motivation and the situations and opportunities available. Teachers with high work motivation will be passionate about contributing all their abilities, thoughts, and skills in realizing educational goals. On the other hand, without work motivation, the teacher will quickly feel bored because there is no driving element to maximize all of his potentials to not be successful in educating / teaching (Rivai \& Murni, 2009). It to 
encouragement/motivation is a sign that what he is doing has met his needs. In other words, teachers who are motivated will work with satisfaction because teachers' needs can encourage teachers to improve their working ability to achieve school education goals optimally and effectively.

In line with the description, it can say that the role of the principal and work motivation is a good factor to determine the level of teacher job satisfaction. This study aims to reveal the influence of the principal's role and work motivation, either separately or collectively, on teacher job satisfaction.

After analyzing it, it turns out that there are many principal roles; there are around seven roles. The seven roles abbreviated as EMASLIM. Namely, the principal as an educator.

1) Principal as an educator. Teaching and learning activities are at the core of the education process, and teachers are the primary implementation and developer of the curriculum in schools. The principal shows a high commitment and focus on curriculum development and teaching activities in his school, of course, will pay attention to the teacher's level of competence (Daryanto, 2011). As educators, school principals must always strive to improve the quality of learning carried out by teachers. In this case, the experience factor greatly influences the principal's professionalism, especially in supporting the formation of understanding of educational staff on the implementation of their duties. The principal effort to improve the performance as an educator, especially in improving other school personnel, includes teachers' upgrades to add insight to the teachers. The principal must also provide opportunities for teachers to improve their knowledge and skills by learning at a higher education level (Mulyasa, 2004).

2) Principal as Manager. One of the duties that must be carried out by the principal is to carry out maintenance and professional development activities for teachers. In this case, school principals should be able to facilitate and provide broad opportunities for teachers to be able to carry out professional development activities through various education and training activities, both carried out in madrasas such as school-level MGMP/ MGP, in house training, professional discussions (Daryanto, 2011). Performing the role and function as a manager, the principal must have the right strategy to empower education personnel through cooperation or cooperation, providing education personnel opportunities in various activities that support school programs. First; Empowering education personnel through cooperation or cooperation means that in increasing the professionalism of education personnel in schools, the principal must prioritize cooperation with education personnel and other parties involved in carrying out activities. Second, to provide educational neighbours opportunities to improve their professions, as the school principal must improve the profession persuasively. Third, to encourage all education personnel's involvement, it means that the head of the madrasah must try to encourage the involvement of all education personnel in every activity at school (Mulyasa, 2004). The role 
of the principal as a manager requires these three kinds of skills, human skills are skills that require special attention from school principals, because through human skills a principal can understand the hearts, attitudes and motives of others, why other people say and behave (Wahjosumidjo, 2011).

3) Principal as Administrator. The principal as an administrator has a very close relationship with various administrative management activities that are recording, compiling and documenting all school programs, especially concerning financial management so that increased teacher competence cannot separate from the cost factor (Mulyasa, 2004). Therefore, the principal should allocate an adequate budget for efforts to increase teacher competence (Daryanto, 2011). As an administrator, the principal, especially in improving school performance and productivity, can be analyzed based on how the approach is, both the trait approach, the behavioural approach, and the situational approach. In this case, the principal must be able to act ideally. In this case, the principal must act situationally, following the existing situation and conditions. In essence, the principal must prioritize duties, so that the tasks assigned to each educational staff can carry out as well as possible. In addition to being task-oriented, the principal must also maintain human relations with his staff so that each educational staff can carry out their duties well. However, they are still happy in doing their job. The principal should be open but still, maintain a distance from education personnel to bring up various problems faced in carrying out their duties as educational staff. Thus, any problems faced by education personnel can be immediately resolved and resolved together. There are no protracted problems that interfere with the main task that must do (Mulyasa, 2004).

4) Principal as a supervisor. Knowing the extent to which the teacher can carry out learning, the principal needs to periodically carry out supervision activities, which can be carried out through class visits to observe the learning process directly, especially in the selection and use of methods, methods used and student involvement in the learning process. From the results of this supervision, it can see that the teacher's weaknesses and strengths in implementing learning. The level of mastery of supervised teacher competencies, then strived for solutions, guidance and specific follow-up so that teachers can improve existing weaknesses while maintaining excellence in implementing learning (Daryanto, 2011)

5) Principal as a leader. The school principal's role as a leader is that the principal must be able to provide guidance and supervision, increase the willingness of education personnel, open two-way communication, and delegate tasks. Among the experts who discuss leadership are Koontz, O'Donnel and Weihrich that what is meant by leadership is an influence, or the process of influencing others, so that they willingly strive towards achieving organizational goals (Wahjosumidjo, 2002).

6) Principals as innovator. The principal's role as an innovator in that the principal must have the right strategy to forge a harmonious relationship with the environment, look for new 
ideas, integrate every activity, provide an example to all educational personnel in the school, and develop innovative learning models.

7) The principal is the motivator. The principal's role as a motivator is to have the right strategy to motivate education personnel to carry out various tasks and functions. Motivation can be grown through the regulation of the physical environment, setting the work atmosphere, discipline, encouragement, appreciation effectively, and providing various learning resources through the development of a learning resource centre (PSB).

The motive is the origin of the word motivation which defined as "driving force" which has become active (Sadirman, 2003). The concept of motivation is quite complicated. Various studies on motivation further expand knowledge about motivation and on the other hand, can obscure the empirical conditions of the definition of motivation. Gelona (2011) explains that "the study of motivation seems to remain a complex subject with apparent minimal progress towards a unifying theory, and many different definitions and descriptions".

Houlfort et al. (2002) defined motivation as motivation because the critical study distinguished between informational and controlling rewards. This statement shows that motivation influenced by someone's information about an object, including how the information is received to carry out a job. Motivation involves a cognitive aspect, describing the stimulus-response and mental conditions that are dynamic. Control motivation, information and reward variables used.

Regarding motivation in general, Robbins and Judge (2013) define it as a process that shows intensity, direction, and effort towards achieving goals. Intensity describes how hard a person tries to benefit the organization - efforts directed at, and consistent with, organizational goals. Motivation has a dimension of persistence which is measured by how long a person can maintain his business. According to Mukharam and Marwansyah (2002), dimensions of work motivation are: 1) internal or intrinsic motivation, and 2) external or extrinsic motivation.

Panggabean (2004) states that the job satisfaction measurement tool used can be The Minnesota Satisfaction Questionnaire (MSQ), which is used by Weiss et al. (1967), The Job Descriptive Index (JDI) developed by Smith and Hulin (1969). Pay Satisfaction Questionnaire (PSQ) by Heneman and Schwab (1985), and Diagnostic Job Survey (JDS) developed by Hackman and Oldman (1974).

The Minnesota Satisfaction Questionnaire (MSQ), is a rating scale to assess the extent to which they are satisfied with some aspects of the job (e.g., satisfaction with salary and opportunities for advancement). Weiss, Dawis, and England developed this measurement of job satisfaction in 1967. This scale consists of jobs that felt to be very dissatisfied, dissatisfied, neutral, satisfying, and very satisfying (Mangkunegara, 2004). A high score reflects a high job satisfaction score as well. 
The Job Descriptive Index (JDI) developed by Smith, Kendall, and Hulin (1969), assesses overall satisfaction using: satisfaction with supervision, satisfaction with coworkers, satisfaction with the job itself, satisfaction with payment, and satisfaction with promotions.

Pay Satisfaction Questionnaire (PSQ) by Heneman and Schwab (1985), is a list of questions aimed at assessing job satisfaction with several aspects of payment (levels, additions, and facilities that can use).

Job Diagnostic Survey (JDS) developed by Hackman and Oldman (1974). develop measurement tools to understand job satisfaction concerning the five core dimensions of job characteristics, namely skill variety, task identity, task significance, autonomy, and feedback (feedback).

Based on the job satisfaction measurement tools above, the dimensions of job satisfaction in this study include (1) satisfaction with salaries, (2) comfort with work, (3) pride in the institution, (4) appreciation for work results, (5) meaningfulness task, (6) opportunity to progress, (7) feedback on the task itself.

\section{METHODS}

The method used in this research is a survey with a quantitative approach. The research design used was a causal design to analyze the relationship/influence between variables, namely the role of the principal (X_1), work motivation (X_2), and teacher job satisfaction (Y).

All variables in this study are measured based on the dimensions that construct each variable. Operationally, the principal's role in this study is the teacher's perception of the principal's role in leading the school. The dimensions used include the role of the principal as (1) educator; (2) managers; (3) advisor; (4) supervisor; (5) leader; (6) innovator; and (7) a motivator (Mulyasa, 2004). Meanwhile, work motivation in this study is a motivation from within the teacher to perform the best educational service tasks so that the stated goals can achieve. The dimensions used to measure work motivation include external motivation and internal motivation (Rivai, 2004). Meanwhile, teacher job satisfaction in this study results from teacher perceptions of how well the job will fulfil his expectations. The dimensions of teacher job satisfaction include: 1) satisfaction with salaries; 2) comfort in employment; 3) pride in the institution; 4) appreciation for work results; 5) the meaningfulness of the task; 6) opportunities to advance; and 7) feedback on the work done (Panggabean, 2004).

This study's population were all teachers of State S School in Larangan District, Brebes Regency, totalling 146 people. The sample calculation technique uses random cluster sampling to determine the minimum sample using the Slovin formula (Riduwan, 2013). Based on the calculation, it knew that the sample in this study amounted to 59 respondents.

Data collection carried out through a questionnaire regarding the Likert scale as a form of construction of the questionnaire's question items with five alternative answers.

Results of the Variable Validity Test of the Principal's Role (X1) shown in Table 1. 
Table 1. Results of the Variable Validity Test of the Principal's Role (X1)

\begin{tabular}{llllllll}
\hline $\begin{array}{l}\text { No. } \\
\text { Item }\end{array}$ & $\mathbf{r}_{\text {count }}$ & rtable & explanation & $\begin{array}{l}\text { No. } \\
\text { Item }\end{array}$ & $\mathbf{r}_{\text {count }}$ & rtabel & explanation \\
\hline 1 & 0.707 & 0.632 & Valid & 11 & 0,795 & 0.632 & Valid \\
2 & 0.772 & 0.632 & Valid & 12 & 0,834 & 0.632 & Valid \\
3 & 0.851 & 0.632 & Valid & 13 & 0,770 & 0.632 & Valid \\
4 & 0.689 & 0.632 & Valid & 14 & 0,768 & 0.632 & Valid \\
5 & 0.808 & 0.632 & Valid & 15 & 0,863 & 0.632 & Valid \\
6 & 0.805 & 0.632 & Valid & 16 & 0,699 & 0.632 & Valid \\
7 & 0.861 & 0.632 & Valid & 17 & 0,785 & 0.632 & Valid \\
8 & 0.887 & 0.632 & Valid & 18 & 0,643 & 0.632 & Valid \\
9 & 0.675 & 0.632 & Valid & 19 & 0,663 & 0.632 & Valid \\
10 & 0.772 & 0.632 & Valid & 20 & 0,891 & 0,632 & Valid \\
\hline
\end{tabular}

The validity test results instruments, for work motivation variables (X2) shown in Table 2.

Table 2. Results of the Variable Validity Test of Work Motivation (X2)

\begin{tabular}{llllllll}
$\begin{array}{l}\text { No. } \\
\text { Item }\end{array}$ & $\mathbf{r}_{\text {count }}$ & rtable & explanation & $\begin{array}{l}\text { No. } \\
\text { Item }\end{array}$ & $\mathbf{r}_{\text {count }}$ & $\mathbf{r}_{\text {table }}$ & Explanation \\
\hline 1 & 0.708 & 0.632 & Valid & 17 & 0.713 & 0.632 & Valid \\
2 & 0.639 & 0.632 & Valid & 18 & 0.719 & 0.632 & Valid \\
3 & 0.686 & 0.632 & Valid & 19 & 0.665 & 0.632 & Valid \\
4 & 0.837 & 0.632 & Valid & 20 & 0.686 & 0.632 & Valid \\
5 & 0.790 & 0.632 & Valid & 21 & 0.633 & 0.632 & Valid \\
6 & 0.866 & 0.632 & Valid & 22 & 0.719 & 0.632 & Valid \\
7 & 0.723 & 0.632 & Valid & 23 & 0.781 & 0.632 & Valid \\
8 & 0.723 & 0.632 & Valid & 24 & 0.820 & 0.632 & Valid \\
9 & 0.717 & 0.632 & Valid & 25 & 0.746 & 0.632 & Valid \\
10 & 0.666 & 0.632 & Valid & 26 & 0.714 & 0.632 & Valid \\
11 & 0.696 & 0.632 & Valid & 27 & 0.909 & 0.632 & Valid \\
12 & 0.832 & 0.632 & Valid & 28 & 0.820 & 0.632 & Valid \\
13 & 0.777 & 0.632 & Valid & 29 & 0.665 & 0.632 & Valid \\
14 & 0.822 & 0.632 & Valid & 30 & 0.785 & 0.632 & Valid \\
15 & 0.641 & 0.632 & Valid & 31 & 0.781 & 0.632 & Valid \\
16 & 0.773 & 0.632 & Valid & & & & \\
\hline
\end{tabular}

The validity research instrument for the teacher job satisfaction variable $(Y)$ shown in Table 3.

Table 3. Results of the Variable Validity Test of Teacher Job Satisfaction (Y)

\begin{tabular}{llllllll}
\hline $\begin{array}{l}\text { No. } \\
\text { Item }\end{array}$ & rcount & Itable & Keterangan & $\begin{array}{l}\text { No. } \\
\text { Item }\end{array}$ & rhitung & rtabel & Keterangan \\
\hline 1 & 0.696 & 0.632 & Valid & 14 & 0.877 & 0.632 & Valid \\
2 & 0.727 & 0.632 & Valid & 15 & 0.670 & 0.632 & Valid \\
3 & 0.731 & 0.632 & Valid & 16 & 0.796 & 0.632 & Valid
\end{tabular}




\begin{tabular}{llllllll}
\hline $\begin{array}{l}\text { No. } \\
\text { Item }\end{array}$ & rcount & rtable & Keterangan & $\begin{array}{l}\text { No. } \\
\text { Item }\end{array}$ & rhitung & rtabel & Keterangan \\
\hline 4 & 0.753 & 0.632 & Valid & 17 & 0.702 & 0.632 & Valid \\
5 & 0.726 & 0.632 & Valid & 18 & 0.689 & 0.632 & Valid \\
6 & 0.727 & 0.632 & Valid & 19 & 0.715 & 0.632 & Valid \\
7 & 0.707 & 0.632 & Valid & 20 & 0.661 & 0.632 & Valid \\
8 & 0.813 & 0.632 & Valid & 21 & 0.772 & 0.632 & Valid \\
9 & 0.731 & 0.632 & Valid & 22 & 0.837 & 0.632 & Valid \\
10 & 0.796 & 0.632 & Valid & 23 & 0.862 & 0.632 & Valid \\
11 & 0.779 & 0.632 & Valid & 24 & 0.803 & 0.632 & Valid \\
12 & 0.733 & 0.632 & Valid & 25 & 0.689 & 0.632 & Valid \\
13 & 0.719 & 0.632 & Valid & & & & \\
\hline
\end{tabular}

Based on the calculation results, the reliability values obtained for each variable X1, X2, and $Y$ saw in Table 4.

Table 4. Result of Variable Reliability Test of $X 1, X 2$ and $Y$

\begin{tabular}{llll}
\hline Variable & $\begin{array}{l}\text { result } \\
r_{\text {count }}\end{array}$ & rtable & explanation \\
\hline Principal's Role $\left(X_{1}\right)$ & 0.963 & 0.632 & Reliable \\
Work Motivation $\left(X_{2}\right)$ & 0.971 & 0.632 & Reliable \\
Teacher Job Satisfaction $(Y)$ & 0.965 & 0.632 & Reliable \\
\hline
\end{tabular}

The data analyzed using the descriptive analysis to determine the general trend of each variable of this study using the formula for the average percentage obtained from the average score of each variable divided by each variable's ideal score and the percentage of value trend with the criteria for interpreting the percentage of research variables, according to Arikunto (2006). At the same time, the research hypothesis testing carried out through correlation and regression analysis. The product-moment correlation formula used to determine the closeness of the relationship between variables is then interpreted based on the interpretation of the correlation coefficient interval proposed by Riduwan (2013). Meanwhile, regression analysis used with a simple linear regression equation and multiple regression (Riduwan, 2013).

\section{RESULTS AND DISCUSSION}

The first hypothesis testing carried out concerning testing the effect of $X_{1}$ on $Y$. In the initial stage, a simple correlation test carried out, the results are summarized in Table 5.

Table 5. Simple Correlation Test for $\mathrm{X} 1$ and $\mathrm{Y}$ variables

\begin{tabular}{lllll}
\hline & $\begin{array}{l}\text { Coefficient } \\
\text { Correlation }\end{array}$ & $\begin{array}{l}\text { Coefficient of } \\
\text { Determination (\%) }\end{array}$ & Significance & \\
\hline$r_{y x_{1}}$ & 0.456 & 20.84 & $t_{\text {hit }}=3.8732$ & $t_{\text {tabel }}=2.0025$ \\
\hline
\end{tabular}


Table 5 knew that the relationship between the principal's role and teacher job satisfaction is 0.456 , which means that the relationship is moderate/strong enough. If the significance test has tested, the result is the t-count value of 3.8732 and the t-table value of 2.0025. Thus the value of tcount> table, so that the effect of the principal's role on teacher job satisfaction is significant. Meanwhile, the calculation result of the coefficient of determination is $20.84 \%$. It shows that the principal's role influences $20.84 \%$ teacher job satisfaction, the remaining $79.16 \%$ influenced by work motivation variables and other variables not examined in this study.

The next stage, a regression calculation is carried out regarding $X_{1}$ on $Y$.The regression testing is shown in Table 6.

Table 6. Regression Test for $X \_1$ against $Y$

\begin{tabular}{lllll}
\hline Variable & Coefficient $(a)$ & $\begin{array}{l}\text { Regresion } \\
\text { Coefficient }(b)\end{array}$ & Cignificance & \\
\hline$X_{1}$ againts $Y$ & 27.04 & 0.82 & $F_{\text {hit }}=3.8732$ & $F_{\text {tabel }}=2.0025$ \\
\hline
\end{tabular}

Based on Table 6, the regression testing results regarding the effect of the variable $X_{1}$ on $Y$ obtained a regression equation in the form of $y^{\wedge}=27.04+0.82 X_{1}$. The constant in the equation is 27.04 , so that if there is no increase in the value of the principal's role variable $\left(X_{1}\right)$, the teacher job satisfaction score $(Y)$ is still 27.04. Next, the equation's regression coefficient is 0.82 , which states that every change in one value of the principal's role will increase teacher job satisfaction by 27.86 . The significance test in this regression uses the F test with the Fcount value is 15.002 , and the Ftable value is 4.010 . Thus, Fcount> Ftable so that the influence of the principal's role on teacher job satisfaction is significant. The above calculations obtain a correlation coefficient of 0.456 , so that $r_{-}(\llbracket y x \rrbracket+1)>0$, then $H_{-} 0$ is rejected, and $H_{-} a$ accepted. Thus, there is a significant effect of principal leadership on teacher job satisfaction.

The first hypothesis testing results supported by the analysis of data descriptions for variables $X_{1}$ and $Y$. Among the seven dimensions of the role of school principals studied, the dimensions of the principal's role as educators and innovators are in the moderate category. In this case, the principal's ability to guide teachers in preparing teaching programs and bring about various breakthroughs to achieve school goals is still considered by respondents in this study to be not optimal. On the other hand, of the seven dimensions of teacher job satisfaction studied, the dimensions of task meaningfulness were in the medium category, especially concerning the preparation of classroom action research by teachers.

Guiding teachers regarding the preparation of teaching programs is one of the principal efforts to improve the quality of learning carried out by teachers. Through these activities, the principal can direct detailed discussions with the teachers regarding the systematic flow analysis of the achievement of more realistic learning objectives because it based on a comparison between the needs of the students' learning process and the available learning situations and facilities as well as the scientific insights of the teachers. School principals and 
teachers can also use the discussion process to find breakthroughs related to education implementation to be used as research themes. As a result, teachers will be motivated to research to meet the requirements for promotion and overcome student learning difficulties. This condition shows a flow where the principal, through his role as an educator and innovator, directs teachers to deepen the meaning of the tasks they carry so that teacher job satisfaction will increase.

The results of this study are in line with the research results of Handayani et al. (2019), which shows that the principal's role as an organizational leader affects teacher satisfaction at work. In this case, it is also in line with You et al. (2017) research results, which shows that collaboration between school principals and teachers related to education decision-making can increase teacher job satisfaction as a result of the formation of self-perceptions that their leaders recognize their abilities. Thus it is proven that the leadership of the principal affects teacher job satisfaction. The higher the leadership quality of the principal, the higher the job satisfaction of the teacher.

Next, testing the second hypothesis that carried out is related to testing the effect of $X_{2}$ on $Y$. In the initial stage, a simple correlation test carried out whose results are summarized in Table 7.

Tabel 7. A simple test correlation $X_{2}$ Variable and $Y$

\begin{tabular}{lllll}
\hline $\begin{array}{l}\text { Correlation } \\
\text { Coefficient }\end{array}$ & $\begin{array}{l}\text { Coefficient of } \\
\text { Determination (\%) }\end{array}$ & Significance & \\
\hline$r_{y x_{2}}$ & 0.550 & 30.30 & $t_{\text {hit }}=4.9775$ & $t_{\text {tabel }}=2.0025$ \\
\hline
\end{tabular}

Table $7 \mathrm{knew}$ that the correlation coefficient of the relationship between work motivation and teacher job satisfaction is 0.550 , which means that the relationship is moderate/strong enough. If the significance test tested, the result is the t-count value of 4.97752 and the t-table value of 2.0025. Thus the value of $t$ count> $\dagger$ table, so that the effect of work motivation on teacher job satisfaction is significant. Meanwhile, the calculation result of the coefficient of determination is $30.30 \%$. It shows that $30.30 \%$ of teacher job satisfaction influenced by work motivation, the remaining $69.70 \%$ influenced by the principal variable's role and other variables not examined in this study.

The next stage, a regression calculation is carried out regarding $X_{1}$ on $Y$.The regression testing is shown in Table 8.

Table 8. Test of Regression for $X 2$ on $Y$

\begin{tabular}{lllll}
\hline Variable & Coefficient $(a)$ & $\begin{array}{l}\text { Regresion } \\
\text { Coefficient }(b)\end{array}$ & Significance & \\
\hline$X_{1}$ terhadap $Y$ & 22.27 & 0.60 & $F_{\text {hit }}=24.776$ & $F_{\text {tabel }}=4.010$ \\
\hline
\end{tabular}

Table 8 refers that the results of regression testing regarding the influence of the $X_{2}$ variable on $Y$ obtained a regression equation in the form of $\mathrm{y}^{\wedge}=22.27+0.60 \mathrm{X}_{2}$. The constant in 
this equation is 22.27, so that if there is no increase in the value of the work motivation variable $\left(X_{2}\right)$, then the teacher job satisfaction score $(Y)$ is still 22.27. Next, the equation's regression coefficient is 0.60 , which states that every change of one work motivation value will increase teacher job satisfaction by 22.87 . The significance test for the regression calculation used the $F$ test with the Fcount value results was 24.776, and the Ftable value was 4.010. The condition is if the value of Fcount> Ftable, it means that the regression coefficient is significant, and vice versa. It means that the effect of work motivation on teacher job satisfaction is significant. The above calculations obtain a correlation coefficient of 0.550 , so that $r_{-}\left(\llbracket y x \rrbracket \_2\right)>0$, then $\mathrm{H} \_\mathrm{O}$ is rejected, and H_a accepted. Thus, there is a significant effect of work motivation on teacher job satisfaction.

The results of testing the first hypothesis also illustrated that the analysis of data descriptions for the $X_{2}$ and $Y$ variables. Between the two dimensions of work motivation, the lowest average score percentage is in the dimension of external motivation, especially related to working conditions shown through unsatisfied learning media availability. Optimal in meeting the work needs of teachers. Whereas in the teacher job satisfaction variable, the lowest average score percentage found in the dimensions of task meaningfulness related to the implementation of CAR. In this case, learning media is a tool that functions and is used to convey learning messages. Therefore, the learning media acts as one of the driving forces for the dynamics of teaching patterns that can be held by teachers. The complete range of instructional media following the teaching material's needs offers a form of control for the teacher to stimulate students' thoughts, feelings, interests, and attention to create a meaningful learning process. When this condition occurs, a positive perception will emerge in the teacher that the teacher's teaching can affect the increase in students' academic mastery so that the teacher's satisfaction with his work performance will increase.

The results of hypothesis testing and the phenomena found in this study are in line with the research results by Karnati and Sibawaihin (2017) which show that self-control in assessing success or failure obtained in carrying out activities will have a direct effect on job satisfaction. In this case, it is also in line with Hakim and Muhdi (2019) research results that job satisfaction significantly influenced by work motivation. Thus, it proves that work motivation affects teacher job satisfaction. the higher the teacher's work motivation, the higher the level of teacher job satisfaction.

Furthermore, testing the third hypothesis that carried out is related to testing the effect of $X_{1}$ and $X_{2}$ simultaneously on $Y$. In the initial stage, multiple correlation testing carried out, the results are summarized in Table 9.

Table 9. Multiple Correlation Test for $X 1$ and $X 2$ with $Y$

\begin{tabular}{lllll}
\hline $\begin{array}{l}\text { Coefficient } \\
\text { Correlation }\end{array}$ & $\begin{array}{l}\text { Coefficient of } \\
\text { Determination }\end{array}$ & Significance & \\
\hline$R_{y x_{1} x_{2}}$ & 0.5901 & $34.82 \%$ & $F_{\text {hit }}=25.3481$ & $F_{\text {tabel }}=3.1588$ \\
\hline
\end{tabular}


Table 9 knew that the relationship between the principal's role and work motivation and teacher job satisfaction is 0.5901 , which means the relationship is moderate/strong enough. If the F test's significance tested, Fcount is 25.3481 and Fable value is 3.1588 so that Fcount> Ftable. Thus, the effect of the principal's role and work motivation on teacher job satisfaction is significant. Meanwhile, the coefficient of determination obtained is $34.82 \%$. It means that the principal and work motivation's role together have a moderate/strong influence on teacher job satisfaction. The rise and fall of teacher job satisfaction $34.82 \%$ are influenced by the principal and work motivation role. The remaining $65.18 \%$ influenced by other variables not examined in this study.

The next stage, a regression calculation is carried out regarding the effect of $X_{1}$ and $X_{2}$ together (simultaneously) on Y.The multiple regression testing summarized in Table 10.

Table 10. Multiple Regression Test for $X_{1}$ and $X_{2}$ for $Y$

\begin{tabular}{lllll}
\hline Constants $(a)$ & \multicolumn{2}{l}{ Regresion Coefficient } & \multicolumn{2}{l}{ Significance } \\
\cline { 2 - 5 } & $\mathrm{b}_{1}$ & $\mathrm{~b}_{2}$ & $F_{\text {hit }}$ & $\mathrm{F}_{\text {tabel }}$ \\
9.070 & 0.438 & 0.469 & 14.9574 & 3.1619 \\
\hline
\end{tabular}

Table 10 refers that the results of regression testing regarding the effect of variables $X_{1}$ and $X_{2}$ simultaneously on $Y$ obtained a regression equation in the form of $Y^{\wedge}=9.070+0.438 X_{1}+$ $0.469 X_{2}$. In this equation, the constant is 9.070 so that if there is no increase in the value of the principal's role variable $\left(X_{1}\right)$ and work motivation $\left(X_{2}\right)$, then the teacher job satisfaction score $(Y)$ is still 9.070. Next, the equation's regression coefficients are 0.438 and 0.469 , which states that each change in the value of the principal's role and work motivation will increase teacher job satisfaction by 9.907 . The significance test for multiple regression is used the F test with the Fcount value results is 14.9574, and the Ftable value is 3.1619. The provisions used are if the value of Fcount> Ftable, it means that the regression coefficient is significant, and vice versa. It means that the effect of the principal's role and work motivation on teacher satisfaction is significant.

From the statistical calculations above, the third hypothesis in this study is that there is a correlation coefficient of $0.5901 . R_{-}\left(x_{-} 1 x_{-} 2 \mathrm{y}\right)>0$ so that the final result $\mathrm{HO}$ rejected, and $\mathrm{H} 1$ is accepted. Thus, there is a significant influence on the principal's role and work motivation together on teacher job satisfaction.

This study's results are in line with Khoiroh (2019), which shows that the principal's leadership style and work motivation together have a significant effect on teacher job satisfaction. In this case, it is also in line with Armstrong's (2006) opinion that job satisfaction influenced by motivational factors, quality of supervision, social relations with workgroups, and the level of success or failure in their work. On the other hand, job satisfaction often associated 
with a person's affective reaction to the job role he performs in achieving predetermined targets. It indicates that when the principal can play the aspect of his leadership appropriately, it will lead to a good working relationship between the principal and teachers. The result will also form trust and work motivation in the teacher. Teachers who are motivated will feel that their work is closely related to fulfilling their own needs. High motivation will increase enthusiasm and excitement at work. This enthusiasm and excitement will motivate teachers to work through extracting interest, desire and curiosity for quality work results, leading to high teacher satisfaction with their work performance. Thus it is evident that the role of the principal and work motivation together affect teacher job satisfaction. The more optimal the principal and teacher work motivation, the higher the level of teacher job satisfaction.

\section{CONCLUSION}

Based on the results of the analysis and discussion that has done, the authors draw the following conclusions; there is a significant influence on the role of the principal on teacher job satisfaction. It means that the influential role of the principals improves teacher job satisfaction. There is a significant effect of work motivation on teacher job satisfaction. it means that work motivation can influence teacher job satisfaction. High work motivation increases teacher job satisfaction. There is a significant influence on the principal's role and work motivation together on teacher job satisfaction. It means that the influential role of the principals and high work motivation improve teacher job satisfaction.

\section{REFERENCES}

Abdullah, M. (2017). Manajemen Mutu Pendidikan di Sekolah Peran Kepemimpinan Kepala Sekolah, Profesionalisme Guru, dan Partisipasi Masyarakat Dalam Peningkatan Mutu Pendidikan di Sekolah. Jurnal Penelitian Pendidikan, 17(3), 190-198.

Amstrong, M. (2006). Armstrong's Handbook of Human Resources Management. Practice (1 1 th Ed.). London: Kogan Page.

Arikunto, S. (2006). Prosedur Penelitian Suatu Pendekatan Praktek. Jakarta: PT. Rineka Cipta. Daryanto. (2011). Kepala Sekolah Sebagai Pemimpin Pembelajaran. Yogyakarta: Gava Media.

Gelona, J. (2011). Does Thinking About Motivation Boost Motivation Levels. The Coaching Psychologist, 7(1), 42-48.

Hakim, A. R., \& Muhdi, M. (2020). Motivasi Kerja dan Kompensasi terhadap Kepuasan Kerja Guru SMK Swasta di Wilayah Timur Kabupaten Pemalang. Jurnal Pendidikan IImu Sosial, 29(2), 105-115.

Houlfort, N., Koestner, R., Joussemet, M., Nantel-Vivier, A., \& Lekes, N. (2002). The Impact of Performance-Contingent Rewards on Perceived Autonomy and Competence. Motivation and Emotion, 26(4), 279-295. 
Karnati, N., \& Sibawaihin, I. (2017). Pengaruh Locus of Control dan Motivasi Instrinsik Terhadap Kepuasan Kerja Guru. Jurnal Sosial Humaniora, 8(1), 29-36.

Khoiroh, N. (2019). Pengaruh Gaya Kepemimpinan Kepala Sekolah dan Motivasi Kerja terhadap Kepuasan Kerja Guru pada Sekolah Dasar Negeri 1 12/1 Perumnas Kecamatan Muara Bulian Kabupaten Batang Hari. Eksis: Jurnal Ilmiah Ekonomi dan Bisnis, 10(1), 2631.

Mangkunegara, A. A. A. P. (2004). Manajemen Sumber Daya Manusia. Bandung: PT. Remaja Rosdakarya.

Marwansyah \& Mukaram. (2002). Manajemen Sumber Daya Manusia. Bandung: Pusat Penerbit Administrasi Niaga Politeknik Negeri Bandung.

Mulyasa, E. (2004). Menjadi Kepala Sekolah Profesional. Bandung: Anggota IKAPI.

Panggabean, S. M. (2004). Manajemen Sumber Daya Manusia. Bogor: Ghalia Indonesia.

Riduwan. (2005). Skala Pengukuran Variabel-variabel Penelitian. Bandung: Alfabeta.

Rivai, V. (2004). Manajemen Sumber Daya Manusia Untuk Perusahaan, Cetakan Pertama. Jakarta, PT. Raja Grafindo Persada.

Rivai, V., \& Murni, S.. (2009). Education Management: Analisis Teori dan Praktik. Jakarta: Raja Grafindo Persada.

Robbins, S.P. \& Judge, T.A. (2013). Organizational Behavior. 15Th Edition. Boston: Pearson.

Saepudin, U., \& Djati, S. P. (2019). Pengaruh Kepuasan Kerja Terhadap Organizational Citizenship Behavior (OCB) Guru dengan Komitmen Organisasional Sebagai Variabel Mediasi. Jurnal IImiah Bisnis, Pasar Modal dan UMKM, 2(1), 123-136.

Sardiman, A. M. (2003). Interaksi dan Motivasi Belajar Mengajar. Jakarta: Raja. GrafindoPersada.

Sari, R. (2018). Motivasi Berprestasi, Kepuasan Kerja dan Manajerial KEpala Sekolah serta Dampaknya terhadap Kinerja Guru.

Singh, S. P., \& Sharma, H. K. (2016). Impact of Work Motivation on Job Satisfaction of Teachers in Professional Education. The International Journal of Research Publications. Research Journal of social science and management, 6(05), 90-96.

Skaalvik, E. M., \& Skaalvik, S. (2017). Motivated for teaching? Associations with school goal structure, teacher self-efficacy, job satisfaction and emotional exhaustion. Teaching and Teacher Education, 67, 152-160.

Suputra, I. P. A. G., Sujana, I. W., \& Novarini, N. N. A. (2019). Pengaruh Iklim Organisasi dan Stres Kerja Terhadap Kepuasan Kerja Guru SMP Negeri 1 Kintamani Bangli

Travers, C. J., \& Cooper, C. L. (1996). Teachers under pressure: Stress in the teaching profession. London: Routledge.

Türkoğlu, M. E., Cansoy, R., \& Parlar, H. (2017). Examining relationship between teachers' selfefficacy and job satisfaction. Universal Journal of Educational Research, 5(5), 765-722.

Wahjosumidjo. (2011). Kepemimpinan Kepala Sekolah. Jakarta: PT. RajaGrafindo Persada. 
Wahjosumidjo. (2002). Kepemimpinan Kepala Sekolah: tinjauan teoritik dan permasalahannya. Jakarta: Raha Grafubdi Persada.

Williams, M., \& Burden, R. L. (1997). Psychology for Language Teachers: A Social Constructivist Approach. New York: Cambridge: University Press.

You, S., Kim, A. Y., \& Lim, S. A. (2017). Job Satisfaction Among Secondary Teachers in Korea: Effects of Teachers' Sense of Efficacy and School Culture. Educational Management Administration \& Leadership, 45(2), 284-297. 